\title{
Socio-Ecological and Livelihood Assessment of Selected Coastal Areas in Sorsogon, Philippines
}

\author{
Arthur B Estrella ${ }^{1}$, Vladimir R. Foronda ${ }^{2}$ and Ma. Teresa B. Lirag ${ }^{3}$ \\ Central Bicol State University of Agriculture (CBSUA), Philippines \\ E-mail: ${ }^{1}$ arthur.estrella@ cbsua.edu.ph, ${ }^{2}$ vladimir.foronda@cbsua.edu.ph, ${ }^{3}$ materesa.lirag@cbsua.edu.ph
}

\begin{abstract}
A study was conducted to assess the productive capacity of five villages namely Gimagaan, Sevilla, Sogoy, Milagrosa and Saclayan in Sorsogon, Philippines. Specifically, it aimed to assess the productive resource base, resource use and livelihood patterns and provide management prescriptions in the transition of farms into organic agriculture. Sustainable livelihoods analysis and participatory rapid appraisal were the analytical frameworks used in the study. Result of the study revealed that Gimagaan village had the greatest access to asset capitals compared to the other four villages in Sorsogon, Philippines. Gimagaan village highly benefited from the presence of socio-civic and government organizations, residents are more socially inclined and actively involved in the various social activities, have generally good access to their natural resource stocks and infrastructure facilities. On sustainability assessment, results revealed that Milagrosa village was more capable of sustaining management systems of its natural resources, highly resilient against perturbations and had greater chances of improving capacities for social development enterprises. Saclayan village on the other hand, had the lowest access to asset capitals and lowest score in terms of sustainability indicators. Management prescriptions include introduction of farming and fishing technologies which do not require intensive capital; conduct of an in-depth study of fishery-based livelihood project; strengthening the establishment of community-based sanctuaries and mangrove areas; introduction of crop-diversification farming system; and strengthening of the production-market linkage for fishery-based livelihood projects.
\end{abstract}

Keywords — productive capacity, socio-ecological assessment, asset capital, sustainability assessment

\section{INTRODUCTION}

The organic agriculture-based social enterprise project is envisioned as a major opportunity at attaining the country's objective of providing alternative and sustainable means of reducing poverty and improving the productive capacities of households and communities. This is also in response to attaining medium-term development goal commitments relative to food security, environmental integrity and education. Given such strategic directions, it is then essential to understand the project beneficiaries' productive capacities in the context of organic agriculture systems as basic foundation for planning, implementation and future evaluation. Agricultural production systems are complex systems. Its behavior and performance as a natural system is influenced by varied elements within the environment. Often, its performance as a system is equated with productivity. The current performance of these production systems or the assessment of its productive capacity are considered as key points of understanding and decision towards setting a platform for a strategic transition to an alternative production system such as organic agriculture.
Therefore, assessing in a holistic and integrated manner the agro-ecological components of the system and their interplay by clearly defining the productivity and other aspects of sustainability of existing farming systems in the area is of paramount importance. The general objective of this project is to assess the productive capacity of selected villagesin Donsol and Castilla, Sorsogon, Philippines and provide management prescriptions thereof. Specifically, it aims to describe and understand the productive capital of selected villages in the bio-physical, socio-economic and technological contexts; assess the productive resource base, resource use and livelihood patterns, including vulnerabilities; provide management and planning guidelines in the transition of farms into organic agriculture; and identify the innovation entry points of the community.

\section{METHODOLOGY}

\section{A. Conceptual Framework}

The project's conceptual model revolves on the idea that agricultural production areas are socio-ecological system (SES). An SES is a system of people and nature or a 
“coupled human-environment system" [10], interacting distinctly and interdependently, creating a unique behavior or performance of the resource system [2]. Simply, an SES consists of a bio-physical unit and its associated social actors and institutions, and is delimited by spatial or functional boundaries surrounding the ecosystem. As is in agricultural production areas, where a spatially defined bio-physical unit of an agri-production ecosystem interacts with the communities (human system) for specific environmental and socio-economic functions. This complex inter-relationships or socio-ecological linkage is manifested as a resource use system in which its behavior ultimately defines the current state of the SES as a natural resource system. Conway (1989) and Marten (1987) also refers to this relationships and linkage as an agro-ecosystem where a complex of biophysical and socio-economic elements are in a bounded area that people have modified for the purposes of agricultural production [5],[7]. This bounded area could be a single field, a household farm, a village or a region. The behavior or performance of the agricultural production system as manifested in patterns could be assessed in terms of a set of systems parameters, productivity and sustainability, among others. Often, this behavior or performance of the SES equates to productivity.

In agricultural production areas, the platform of this critical socio-ecological link is land which is defined a productive asset. Its productivity is invariably a consequence of a complex of factors such as land use, population and livelihood, institutions and policies, among others as expressed in patterns of the agricultural production subsystem. To proceed with a development intervention to manage the SES as a sustainable production system, it is essential to understand these factors and its attendant trends and patterns in the context of sustainability and other parameters such a vulnerability and resiliency (Figure 1).

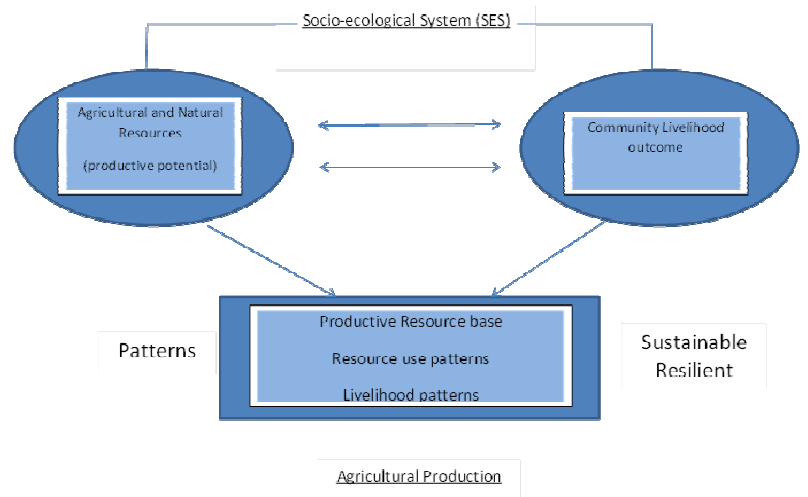

Fig. 1 Conceptual Framework

\section{B. Methodological Framework}

Given the project objectives, the methodological approach is anchored on two resource use assessment frameworks. These frameworks shall interweave with each other to give a deeper and meaningful insight into the interactions of the natural resource base, livelihood systems and the ecosystem as a whole. The first, is the agro-ecosystems framework [5],[7] which considers agricultural production areas as a bounded natural resource system modified by man for productive purposes and its behavior and performance as a system is assessed in terms of the systems' properties (productivity, stability, sustainability, equitability and autonomy). Likewise, the interaction of varied elements in the agro-ecosytem is manifested in terms of patterns (spatial, temporal, flow and decision) which depicts the behavior of the system. Considering such, the agro-ecosystems analysis proceeds in a logical manner which includes: (1) definition of the system boundaries and hierarchy, (2) patterns analysis, (3) systems property assessment, (4) formulation of a development hypothesis and (5) formulation of management prescriptions. Essentially, the agro-ecosystems analysis and development $(\mathrm{AAD})$ would provide a deeper understanding of productivity and the resource base given the interactions of exogenous and endogenous factors in the system, assess the performance of the system given the factors and provide management prescriptions considering sustainability and resiliency indicators.

The second, is sustainable livelihoods analysis [9], [6] which looks at livelihood system "comprising of capabilities, assets (including both material and social resources) and activities required for a living" [3] and this livelihood system experiences shocks and stresses as it interacts with various factors in the resource system. Carney (1998) explains that a livelihood is sustainable if it can cope and recover from these stresses and shocks [1]. As such, the sustainable livelihoods analysis looks at the various elements (conditions/trends, resources, institutions/ processes/ structures, livelihood strategies and outcomes of the livelihood system to assess whether the system is sustainable given the interplay of the various elements in the livelihood system.

Participatory rural appraisal (PRA) provides a flexible support tool to gather data and consolidate data in a participatory manner. In fact, PRA aggregates and consolidates the data elements of both analytical tools into one cohesive data set while maintaining its distinct analytical context and validity. Likewise its adoption as a support tool shall enhance early appreciation and acceptance of proposed project initiatives.

The combination of these analytical frameworks provided a clear understanding of the interactions and processes as expressed in patterns in the SES and in the agricultural production subsystem. Ultimately, by using indicators, an assessment of the SES and the agricultural production subsystem in terms of sustainability and resiliency followed. Figure 2 graphically presents the productive capacity assessment framework relative to the 2 major productive capacity assessment tools.

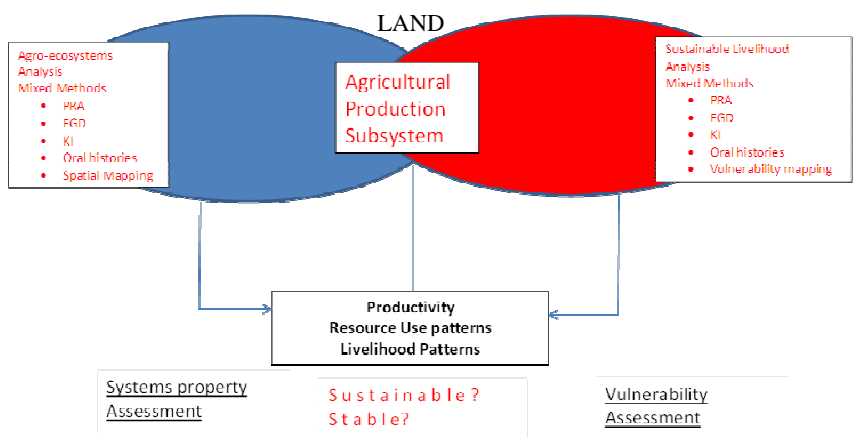

Fig.2 Methodological Framework 


\section{RESULTS AND DISCUSSION}

The research project covers the villages of Gimagaan and Sevilla in Donsol and villages Sogoy, Milagrosa and Saclayan in Castilla, Sorsogon. These villages are approximately 7-10 kilometers away from the town proper. Generally, these villages have vast areas for agricultural production and the residents are involved in rice, coconut and copra production with short term crops grown for their daily sustenance. Also, with the proximity of Gimagaan and Saclayan villages to the coastal area, the populace engage themselves into fishing and seaweed farming. Likewise, these villages have various physical structures which are crucial in the smooth day-to-day operation of the people. They have school facilities, assemble halls, chapel, health center, and outposts to name a few.

In terms of financial capital, about $30 \%$ of the households belong to middle income group. The bigger portion of the village population belongs to the lower income bracket or the poor which is about sixty percent $(60 \%)$ of the total population. These are the laborers, who do not have their own residential lands or farms, tenants who are engaged in planting root crops, farmers who devote their time into planting vegetables or selling dried fish and small-scale fishermen with earnings ranging between Php3,000 - 9,000 monthly. A very small percentage of about $5 \%$ can be considered as rich. These are the rich and affluent who own beach resorts, with houses which are made of concrete and sturdy materials, are able to finish college degree with an earning capacity between Php 10,000-20,000 monthly and own cars and household appliances. Likewise, a small $5 \%$ of the total population is considered very poor whose income range from Php 2,000- 5,000 pesos per month. Tables 1 and 2 show the comparative rating of the 5 villages in terms of natural, social, financial, physical and human capital.

The asset pentagon was used as a visual representation of the extent of access of village residents in terms of natural, social, financial, human and physical capital in the area. Generally, all villages highly benefited from the presence of several socio-civic organizations and government organizations which help them live securely. The pentagon shows the social capital having the highest rating of $80 \%$. Village residents are socially inclined and actively involved in the various social activities being conducted in the area. Likewise, the 5 villages have generally good access to their natural resource stocks as well as infrastructure facilities. The physical capital in the area provides the needs of the residents. In terms of human and financial capital however, the villages have low access due to limited presence of organizations which can help and assist them financially. There is limited presence of lending institutions and service organizations which can help them become more financially secure and stable. The low human capital is related to the high number of population who belong to the poor category.

Over-all, Gimagaan showed the highest access to asset capital followed by Milagrosa, Sevilla and Sogoy villages. Saclayan village on the other hand, had the lowest access to these livelihood assets (Figure 3).

The current realities/situation existing in the area vis a vis the sustainability indicators was analyzed. Village residents were asked to rate the degree of sustainability of the village based on these sustainability criteria/indicators. The Likert 4 point rating scale was used with the following descriptors: 4 - Highly sustainable; 3 - Moderately Sustainable; 2 Slightly sustainable and 1 - not sustainable (Table 3).

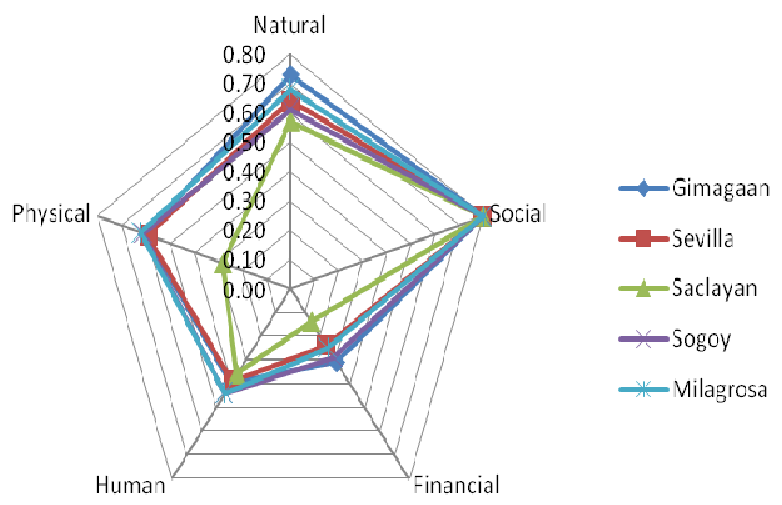

Fig.2 ASSET Pentagon for Selected Coastal Villages,Sorsogon, Philippines

TABLE I

COMPARATIVE RATING OF LIVELIHOOD ASSETS FOR SELECTED COASTAL VILLAGES, SORSOGON, PHILIPPINES

\begin{tabular}{|c|c|c|c|c|c|}
\hline Livelihood Asset & $\begin{array}{c}\text { Gima } \\
\text { gaan }\end{array}$ & Sevilla & $\begin{array}{c}\text { Sacla } \\
\text { yan }\end{array}$ & Sogoy & $\begin{array}{c}\text { Mila } \\
\text { grosa }\end{array}$ \\
\hline 1. Access to Natural Capital & 0.73 & 0.64 & 0.57 & 0.61 & 0.68 \\
\hline Farm with Water Sources & 85 & 65 & 30 & 60 & 80 \\
\hline Fuel Sources & 70 & 55 & 65 & 80 & 80 \\
\hline Land For Cultivation & 70 & 85 & 80 & 85 & 85 \\
\hline Fisheries & 90 & 40 & 95 & 10 & 10 \\
\hline Vegetables and other plants & 50 & 70 & 40 & 70 & 70 \\
\hline House with water & 70 & 70 & 30 & 60 & 80 \\
\hline 2. Access to Social Capital & 0.80 & 0.80 & 0.80 & 0.85 & 0.80 \\
\hline Participation Rate to Activities & 80 & 80 & 80 & 85 & 80 \\
\hline $\begin{array}{l}\text { 3. Access to Financial } \\
\text { Capital }\end{array}$ & 0.31 & 0.24 & 0.14 & 0.29 & 0.25 \\
\hline Rate of People with Loans & 85 & 75 & 35 & 85 & 75 \\
\hline Rate of People with Savings & 25 & 10 & 5 & 15 & 10 \\
\hline $\begin{array}{l}\text { Rate of People with } \\
\text { Remittances }\end{array}$ & 5 & 5 & 5 & 5 & 5 \\
\hline $\begin{array}{l}\text { Rate of People with Liquid } \\
\text { Assets }\end{array}$ & 10 & 5 & 10 & 10 & 10 \\
\hline 4. Access to Human Capital & 0.40 & 0.39 & 0.36 & 0.44 & 0.44 \\
\hline $\begin{array}{l}\text { Rate of HH sending children to } \\
\text { school }\end{array}$ & 90 & 90 & 90 & 90 & 90 \\
\hline Literacy Rate & 70 & 70 & 60 & 85 & 85 \\
\hline Rate of People with PhilHealth & 15 & 10 & 5 & 20 & 20 \\
\hline Elementary Graduate & 90 & 90 & 90 & 90 & 90 \\
\hline High School Graduate & 50 & 50 & 40 & 60 & 60 \\
\hline College Graduate & 15 & 15 & 10 & 20 & 20 \\
\hline $\begin{array}{l}\text { Vocational Course Degree } \\
\text { Holder }\end{array}$ & 5 & 5 & 5 & 10 & 10 \\
\hline Job Opportunities & 5 & 5 & 5 & 5 & 5 \\
\hline Employment Rate & 20 & 15 & 15 & 15 & 20 \\
\hline 5. Access to Physical Capital & 0.60 & 0.59 & 0.28 & 0.61 & 0.62 \\
\hline House Ownership & 85 & 90 & 95 & 80 & 80 \\
\hline Availability of Electricity & 95 & 90 & 60 & 95 & 95 \\
\hline $\begin{array}{l}\text { Availability of } \\
\text { Communication Lines }\end{array}$ & 85 & 80 & 15 & 85 & 85 \\
\hline Availability of Pipe Water & 0 & 0 & 0 & 0 & 0 \\
\hline \multicolumn{6}{|l|}{ House Type } \\
\hline Concrete & 15 & 25 & 10 & 10 & 10 \\
\hline Semi-Concrete & 75 & 60 & 50 & 50 & 45 \\
\hline Light Materials & 10 & 15 & 40 & 40 & 45 \\
\hline \multicolumn{6}{|l|}{ Vehicle } \\
\hline Bike/single motor & 80 & 85 & 10 & 90 & 90 \\
\hline Tricycle & 85 & 80 & 0 & 90 & 90 \\
\hline Private Cars & 40 & 30 & 25 & 40 & 45 \\
\hline $\begin{array}{l}\text { Infrastructure for } \\
\text { Transportation }\end{array}$ & 95 & 95 & 0 & 95 & 95 \\
\hline
\end{tabular}


TABLE II

Asset CAPITALs For SElected CoAstal Villages, SoRsogon, PHILIPPINES

\begin{tabular}{|l|c|c|c|c|c|c|}
\hline Village & Natural & Social & Financial & Human & Physical & Mean \\
\hline Gimagaan & 0.73 & 0.80 & 0.31 & 0.40 & 0.60 & 0.57 \\
\hline Sevilla & 0.64 & 0.80 & 0.24 & 0.39 & 0.59 & 0.53 \\
\hline Saclayan & 0.57 & 0.80 & 0.14 & 0.36 & 0.28 & 0.43 \\
\hline Sogoy & 0.61 & 0.80 & 0.29 & 0.44 & 0.61 & 0.55 \\
\hline Milagrosa & 0.68 & 0.80 & 0.25 & 0.44 & 0.62 & 0.56 \\
\hline
\end{tabular}

By thematic area, the four villages except for Saclayan have comparatively the same score in terms of its capability to introduce sustainable management systems for its natural resources. Gimagaan and Milagrosaare highly resilient villages compared to Sevilla, Saclayan and Sogoy. The ability to increase capacities for social development enterprises was generally high for Milagrosa, Sogoy and Gimagaan villages but lowest for Saclayan village. Over-all, results showed that Milagrosa village had the highest sustainability score (42) and Saclayan village had the lowest score (31).

TABLE III

COMPARATIVE RATING ON SUSTAINABILITy INDICATORS FOR SELECTED COASTAL B ARANGAYS, SORSOGON, PHILIPPINES

\begin{tabular}{|c|c|c|c|c|c|c|c|}
\hline Themes & Sustainability Indicators & $\%$ Weight & Gimagaan & Sevilla & Saclayan & Sogoy & Milagrosa \\
\hline \multirow{5}{*}{$\begin{array}{l}\text { Introduction of } \\
\text { sustainable } \\
\text { Management } \\
\text { Systems of Natural } \\
\text { Resources }\end{array}$} & Usage of Organic Inputs in production & $10.00 \%$ & 2 & 2 & 2 & 2 & 3 \\
\hline & Cropping Diversity & $10.00 \%$ & 2 & 3 & 2 & 3 & 3 \\
\hline & Livelihood Mix & $10.00 \%$ & 3 & 3 & 2 & 3 & 3 \\
\hline & Agricultural Production & $10.00 \%$ & 3 & 3 & 3 & 3 & 2 \\
\hline & Sub-total & & 10 & 11 & 9 & 11 & 11 \\
\hline \multirow{4}{*}{$\begin{array}{l}\text { Strengthening of } \\
\text { Community } \\
\text { Resiliency }\end{array}$} & $\begin{array}{l}\text { Exposure of farm and the community to } \\
\text { climate-related risks }\end{array}$ & $10.00 \%$ & 3 & 2 & 2 & 2 & 3 \\
\hline & Incidence of Crop Failure & $10.00 \%$ & 3 & 2 & 2 & 2 & 3 \\
\hline & Usage of inorganic inputs in production & $10.00 \%$ & 2 & 1 & 1 & 1 & 2 \\
\hline & Sub-total & & 8 & 5 & 5 & 5 & 8 \\
\hline \multirow{8}{*}{$\begin{array}{l}\text { Increasing capacities } \\
\text { for social } \\
\text { development } \\
\text { enterprises }\end{array}$} & Access to buyers & $4.29 \%$ & 4 & 3 & 3 & 4 & 4 \\
\hline & $\begin{array}{l}\text { Access of Community to technological } \\
\text { support }\end{array}$ & $4.29 \%$ & 2 & 2 & 2 & 3 & 3 \\
\hline & Access to financial capital & $4.29 \%$ & 3 & 2 & 2 & 4 & 4 \\
\hline & Access to transport & $4.29 \%$ & 4 & 2 & 3 & 3 & 3 \\
\hline & $\begin{array}{l}\text { Presence of local support institution to } \\
\text { facilitate access to livelihood assets }\end{array}$ & $4.29 \%$ & 3 & 3 & 2 & 3 & 3 \\
\hline & $\begin{array}{l}\text { Degree of participation of women on } \\
\text { livelihood efforts }\end{array}$ & $4.29 \%$ & 2 & 3 & 3 & 3 & 3 \\
\hline & Sub-total & & 21 & 18 & 17 & 23 & 23 \\
\hline & GRAND TOTAL & & 39 & 34 & 31 & 39 & 42 \\
\hline
\end{tabular}

\section{CONCLUSIONS}

Based on the field results and secondary data gathered, it revealed that majority of the village residents belong to the middle and poor social class. Some residents are already practicing organic farming in their backyard vegetable production through the use of decomposed organic material.

Gimagaan village has the greatest access to asset capital. It has transformed its community from a once laidback village to a tourist attraction to foreigners because of the presence of its pristine resorts. Likewise, it continuously build its community as evidenced by the presence of additional structures and amenities and the residents weave the future characterized by the virtues of religiosity, courtesy, friendliness and hospitality. This village is also highly accessible and can be easily reached using public utility vehicle such as tricycle and motorbike. Marketing of farm products is easy for producers and buyers can get hold of these products without much difficulty compared to other villages in Sorsogon. Some residents are already practicing organic farming in their backyard through the use of dried organic materials such as 'dayami' hence, they seldom use fertilizer for their vegetables. Majority however, are still using the 50-50 ratio for organic-commercial fertilizer application in their farms.

Saclayan on the other hand, has the least access to asset capital. The major source of income of the residents is seaweed farming/culturing and fishing. The village is rural in nature, far from the central district of Sorsogon with only a handful of institutions extending assistance to them.Agricultural/farm crops are unfavorably affected by extreme weather condition or intense heat. This is the basic complain of the residents especially because farmlands are rainfed. To a large extent, these undesirable weather conditions do not only directly affect the small crops but the forest, the sea and the mangrove areas as well. There are decreasing number of mangrove areas which adversely affect the habitat of mangroves, fish and marine resources. The produce of coconut farms is also affected when there is El Niño and food reserve of the community significantly decreases.Likewise, the current situation is that the village is accessible by sea transport. An alternative transport system by land that can connect the village to other nearby towns is critical to increase its accessibility to livelihood assets.

The village of Milagrosa showed the highest score in terms of assessing the sustainability of the area. Milagrosa is more capable of sustaining management systems of its 
natural resources, highly resilient against perturbations and had greater chances of improving capacities for social development enterprises. Both Gimagaan and Sogoy villages ranked second followed by Sevilla and Saclayan which ranked third and fourth, respectively as shown by their sustainability indices.

Over-all, Sogoy and Sevilla villages showed moderate access to asset capitals and their sustainability index also indicate that they are moderately sustainable. These villages experience severe flooding when there are typhoons which adversely affect their crops and farms. Likewise, intense heat or El Niño resulting to drought is also being experienced. These unprecedented environmental disasters do not happen yearly but when it comes, severe chaos and malady are being experienced by the residents such as illnesses, lack of food and water and destruction of their houses.However, despite these calamities, village residents are able to cope because of the 'bayanihan' spirit and oneness. Just like in other villages in Sorsogon, some residents (20\%)still rely on the use of inorganic fertilizers and traditional farming with the use of synthetic fertilizer is also observed. However, majority of the households are already adopting the use of organic fertilizer

\section{RECOMMENDATIONS}

The barangay residents will benefit much if they will have more produce out of coconut and rice farming. Relative to this, technologies may be introduced and taught which do not require intensive capital to farmers.

Alternative production technology which is not cost intensive can be explored. The residents must fully understand that the focus of organic farming is to provide them an alternative livelihood source which is eco-friendly and will promote environmental integrity. Adoption of organic rice farming in the rice fields of the barangay, which is only limited in area, can be tested using local materials such as decomposed rice straw and animal manure (hogs and ruminants). The current practice of 50-50 ratio for organiccommercial fertilizer application in their farms can be a good start towards organic farming.

The agricultural farms in the barangay showed indications of being a potential area for native beekeeping project/apiary establishment ApisCerana- "ligwan" andTrigona Biroi which is locally known as"kalulot" or"lukot". In the coconut production area, particularly in less-dense planted farms, crop-diversification approach by integrating perennial crops, can still be advocated for adoption. Provision of perennial crops produced either through a collective nursery production project of fruit-bearing trees of the community or directly provided by a project to the farmers, will be helpful to facilitate its adoption. Training of farmers on plant nursery development the establishment in their own farms or individual backyard will be another development option to the project towards a more sustainable production of planting materials by the respective recipients. Through this approach, farming families will be more empowered to collect seeds of trees based on their preference in terms of characteristics, adaptability in their farms and market potentials. There is also a need to strengthen the productionmarket linkage which is vital to the success of the transition from their traditional farming to organic-based farming. There is a need for the establishment of demonstration farm on organic agriculture. While some residents strongly advocate the use of organic fertilizers, it is important for them to actually see that an organic-based farm is feasible and will be able to provide the food requirement of the community in general and of each family in particular. A more comprehensive feasibility study of fishery-based livelihood project must be done. If families will have complete fishing resource materials, they will be assured of a more stable livelihood through-out the year that is more environment- friendly and sustainable. An example of integrated fishing resources are for seaweed production, crab harvesting cages, simple fishing gears, etc. To support the sustainability of fishery-based livelihood projects, planting of mangrove and establishment of community-based sanctuaries in partnership with the LGU, DENR and SABFAR must be encouraged.

\section{ACKNOWLEDGMENT}

The researchers wish to acknowledge the funding support given by Intervida Foundation, Philippines for this project. Likewise, we are grateful for the administrative support of the key officials of the Central Bicol State University of Agriculture in the implementation of this project.

\section{REFERENCES}

[1] Carney, D., 1998. Implementing the sustainable rural livelihoods approach, Department for International Development, London, United Kingdom.

[2] Carpenter, Stephen, 2011. What is a socio-ecological system, BioComplexity Project, Stockholm Resilience Center.

[3] Chambers, R., and G. Conway. 1992. Sustainable Rural livelihoods: Practical concepts for the 21st century. IDS working paper 296. Institute of Development Studies, Brighton, United Kingdom.

[4] Conway, G., Sajise, P. and W. Knowland. 1989. Lake Buhi: Resolving Conflicts in a Philippine Development Project, Ambio Vol 18.

[5] Conway, Gordon 1989 Agroecosystems Analysis, Imperial College, London.

[6] DFID, Sustainable Livelihoods Guidance Sheets (2001-02).

[7] Marten, Gerald 1987 Productivity, Stability, Sustainability, Equitability and Autonomy as Propertiesfor Agroecosystem Assessment Agricultural Systems26: 291-316.

[8] Sallu, S., Twyman, C., and Lindsay Stringer 2010 Resilient or vulnerable livelihoods? Assessing livelihood Dynamics in Rural Bostwana. Ecology and Society Vol 15 no. 4.

[9] Scoones, Ian 1998 Sustainable rural livelihoods: A framework for Analysis IDS working paper 72.

[10] Young, Oran, and Frans Berkhout, Gilberto Gallopoin, Marco Jannssen, Elinor Ostrom \& Sander van der Leeuw , 2005 How will globalization affect resilience, vulnerability and adaptability of Socio-elogical systems, Global Environmental Change Vol 16.

[11] Barangay Profile prepared by Ms. Edith Talagit completed on May 15, 2008.

[12] Participatory Rural/Rapid Appraisal conducted by CBSUA on February 5-6, 2012.

[13] Validation Workshop conducted by CBSUA on May 3, 2012. 